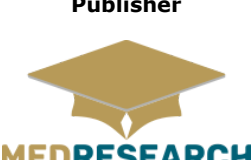

MEDRESEARCH

www.medresearch.in

\title{
Knowledge, Attitude and Practices of Parents of Thalassemic Children in District Patiala, Punjab, India
}

\author{
Singh G. ${ }^{1}$, Mitra Y.. ${ }^{*}$, Kaur K. ${ }^{3}$, Bhardwaj K. \\ DOI: https://doi.org/10.17511/ijphr.2019.i1.04
}

\footnotetext{
${ }^{1}$ Gurmeet Singh, Professor, Blood Bank, Government Medical College, Patiala, Punjab, India.

2* Yash Mitra, Assistant Professor, Department of Community Medicine, Punjab Institute of Medical Sciences, Jalandhar, Punjab, India.

3 Kamaldeep Kaur, Medical Officer under DHS, Blood Bank, Government Medical College, Patiala, Punjab, India.

${ }^{4}$ Kanchan Bhardwaj, Professor and Head, Blood Bank, Government Medical College, Patiala, Punjab, India.
}

Introduction: $\beta$-thalassemia is an autosomal recessive single gene disorder characterized by defective production of hemoglobin and excessive destruction of Red Blood Cells. The defect causes an abnormal development of Red Blood Cells and ultimately anemia. The cultural and religious scenario in Muslims, Khatris and Punjabis migrated from Pakistan is such that consanguineous marriages are quite common. There is no concept of premarital screening of counseling of individuals with a family history of disease. The only way to prevent the disease and to reduce the morbidity and mortality is by educating the general population. Objectives: To assess the Knowledge, Attitude and Practices of Parents of Thalassemic Children. Methods: The study was conducted on parents of 100 patients of thalassemia who are coming regularly for blood transfusion in Thalassemia Day Care Centre (TDCC) run by Patiala Thalassemic Children Welfare Association (PTCWA) at Rajindra Hospital, Patiala to collect the relevant data for the study to evaluate the Knowledge, Attitude and Practices (KAP) of parents of thalassemic children. Results: Mean age of the patients was 8.36 years. $66 \%$ patients were males and $34 \%$ were females. $41 \%$ of the patients were from Khatri community and $59 \%$ were from other communities. Family history of thalassemia was present in $23 \%$ of the cases and history of consanguineous marriage was present in $4 \%$ of the cases. Seventy six percent of the parents knew about the prenatal diagnosis that could be performed to prevent the birth of thalassemic children. Conclusion: There should be a community based educational efforts to increase awareness of this problem especially to the people from low socioeconomic class and from rural area. Control of thalassemia requires treatment of the individual patients as well as a community based educational effort to increase the awareness of this problem.

Keywords: Thalassemic, Glovin, Cultural, Translaplation, Therapy

Corresponding Author

Yash Mitra, Assistant Professor, Department of Community Medicine, Punjab Institute of Medical Sciences, Jalandhar, Punjab, India.

Email: mitrayash@yahoo.com
How to Cite this Article

Singh G, Mitra Y, Kaur K, Bhardwaj K. Knowledge, Attitude and Practices of Parents of Thalassemic Children in District Patiala, Punjab, India. Public Health Rev Int J Public Health Res. 2019;6(1):25-34. Available From https://publichealth.medresearch.in/index.php/ijphr/ article/view/97
To Browse

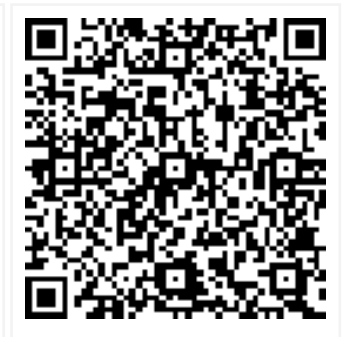

Manuscript Received 2019-01-30

Conflict of Interest No
Review Round 1 2019-02-08

Funding

Nil

Review Round 2
2019-02-15
$\begin{gathered}\text { Ethical Approval } \\ \text { Yes }\end{gathered}$

Review Round 2

Yes
Review Round 3

Plagiarism X-checker $6 \%$
Accepted 2019-02-20

Note

(C) 2019 by Gurmeet Singh, Yash Mitra, Kamaldeep Kaur, Kanchan Bhardwaj and Published by Siddharth Health Research and Social Welfare Society. This is an Open Access article licensed under a Creative Commons Attribution 4.0 International License https://creativecommons.org/licenses/by/4.0/ unported [CC BY 4.0]. 


\section{Introduction}

B-thalassemia is an autosomal recessive single gene disorder characterized by defective production of hemoglobin and excessive destruction of Red Blood Cells. Hemoglobin is formed of four protein subunits, normally two a and two $\beta$. Genetic mutation in the gene encoding for $\beta$ subunits of proteins, results in reduced or totally absent synthesis of $\beta$ globin chain leading to the formation of abnormal hemoglobin or even to the absence of $\beta$ hemoglobin. The defect causes an

Abnormal development of Red Blood Cells and ultimately anemia [1]. Mainstay of therapy of thalassemia major is transfusion therapy and management of its complications. Hyper transfusion remains the most accepted regimen in most parts of the world in which the hemoglobin level above a minimum of $10 \mathrm{~g} \%$ is maintained [2].

Only definitive therapy available for thalassemia major which gives permanent cure is bone marrow transplantation, which is available at very few centres and cost is very high and is about 50,000 USD in developing countries [3].

It has been estimated that more than $1,00,000$ people are born every year all over the world with thalassemia and 10,000 in India alone. Prevalence of thalassemia in India is $3.3 \%$ in general population and $8-15 \%$ among certain communities and religions such as Sindhis, Punjabis, Khatris from North, Bengalis, Jains and Muslims. Prevalence of $\beta$ thalassemia in Punjabis is $3.0-6.5 \%$.

Incidence in children of Punjabi origin was $7.6 \%$ in Delhi in 2010 [4] [5] [6]. The cultural and religious scenario in Muslims, Khatris and Punjabis migrated from Pakistan is such that consanguineous marriages are quite common. There is no concept of premarital screening of counseling of individuals with a family history of disease. The concept of termination of pregnancy is an ethical and religious issue in some communities [7].

Improvement of quality of patient care, reinforcement of medical education and enhanced efforts by clinical staff to provide practical knowledge to patients with thalassemia major should significantly improve patient's adherence to treatment [8]. The preventive measures have already been adopted successfully worldwide especially in Cyprus and Sardinia where the disease has almost been prevented.
In the prevention of $\beta$ thalassemia, social scientists and counselors have a major role to play. The Govt. teaching hospitals, inspite of tertiary level referral hospitals in states have to serve people from all socio economic strata and have to cater to all sorts of ailments, ranging from the simplest infections to highly complicated chronic illnesses.

Thus they are often overcrowded and the staff is over-burdened to offer repeated counseling and sustained motivation to parents of children suffering from genetic disorders. On the other hand there are specialized Non Govt. Organizations (NGOs) that manage these disorders specifically and therefore, can devote more effort on the very important preventive counseling aspect of these disorders apart from therapeutic intervention [9].

Arif et al (2008) conducted a study to determine the awareness among parents ofchildren with thalassemia major regarding the disease. A total 120 care takers were questioned. Majority was of low socioeconomic class and $66.7 \%$ were illiterate. Only $15.8 \%$ knew the importance of blood screening.

Knowledge regarding deferral was present in $55 \%$ of the parents but only $10.9 \%$ of the patients were receiving it adequately. Only $15 \%$ knew that thalassemia is an inherited disorder and family screening of siblings and antenatal diagnosis in subsequent pregnancies was done in $5.8 \%$ and $5 \%$ respectively. They concluded that awareness of parents regarding the disease was inadequate.

General public and parents of thalassemic children should be sensitized in this regard [7]. The only way to prevent the disease and to reduce the morbidity and mortality is by educating the general population and best way is to improve the knowledge and awareness of parents of thalassemic children about the disease, its prevention and treatment options available in our country.

They can serve as messengers in the society. They will adhere to treatment regimens and birth of another child in the family with thalassemia can be prevented. For this reason, present study was taken to evaluate the knowledge, attitude and practices of parents of thalassemic children.

\section{Objectives}

To assess theknowledge, attitude and practices (KAP) of parents of Thalassemic children. 


\section{Material and Methods}

Setting and Type of Study: The study was conducted in the Department of Paediatrics of Rajindra Hospital and Medical College, Patiala from January 2011 to November 2012. It is a crosssectional study.

Sampling Method: Interview Technique was used to fill the predesigned and pretested proforma.

Sample Collection: Parents of 100 patients who were coming regularly to have blood transfusion from thalassemia day care centre run by Patiala Thalassemic Children Welfare Association at the Paediatrics Department of Rajendra Hospital, Patiala.

Inclusion Criteria: All the patients coming for regular blood transfusion in the centre from 0 yrs. to 15 yrs. of age and submitted the written consent to participate in the study.

Exclusion Criteria: Those patients who had not given written consent and are not coming for regular transfusion in the centre during the period of study.

Statistical Methods: The variables were compared by Chi Square Test and results so obtained were analysed using SPSS Version 15 and level of significance was determined as its ' $P$ ' value with $\mathrm{P}<0.05$ taken as statistically significant.

Various levels are

- P>0.05 Non Significant

- $P<0.05$ Significant.

Ethical Consideration and Permission: was obtained from the Institutional Committee, Medical College Patiala.

Scoring System: The patients were divided into four groups according to age i.e. 0-4 years; 5-9 years; $10-14$ years and 15 years and into five groups according to socio-economic status of the patients applying Kuppuswamy Scale. The patients were also divided into three groups on the basis of number of questions regarding knowledge correctly answered i.e. 0-5; 6-10 and 11-15.

Surgical Procedure: During the period of study, surgical procedure was adopted for Spleenectomy.

\section{Results}

The key findings of the study as below:
Table 1 shows that Mean age of the patients was 8.36 years.

Table-1:Age and Sex Wise Distribution of the Patients.

\begin{tabular}{|l|l|l|l|}
\hline \multirow{2}{*}{ Age in Years } & \multicolumn{2}{|c|}{ Sex } & \multirow{3}{*}{ Total } \\
\cline { 2 - 3 } & Male & Female & \\
\cline { 2 - 3 } & No. (\%age) & No. (\%age) & \\
\hline $0-4$ & $19(76 \%)$ & $6(24 \%)$ & 25 \\
\hline $5-6$ & $19(55.9 \%)$ & $15(44 \%)$ & 34 \\
\hline $10-14$ & $22(78.6 \%)$ & $6(21.4 \%)$ & 28 \\
\hline 15 & $66(66 \%)$ & $34(34 \%)$ & 100 \\
\hline
\end{tabular}

Table 2 shows that $43 \%$ were from rural area and $57 \%$ patients were from urban areas. $66 \%$ patients were males and $34 \%$ were females.

Table-2: Geographical Area Wise Distribution of Patients.

\begin{tabular}{|l|l|l|}
\hline \multicolumn{1}{|c|}{ Area } & \multicolumn{1}{c|}{ Number } & \multicolumn{1}{c|}{ \%age } \\
\hline Rural & 43 & $43 \%$ \\
\hline Urban & 57 & $57 \%$ \\
\hline Total & 100 & $100 \%$ \\
\hline
\end{tabular}

Table 3 depicts that Age diagnosis was 0-6 months in $63 \%$ of cases, $7-12$ months in $27 \%$ of cases and $10 \%$ cases were diagnosed between $1-3$ years of age. $100 \%$ of the patients were diagnosed within 3 years of age.

Table-3: Distribution of the Patients According to the Age at the Time of Diagnosis.

\begin{tabular}{|l|l|l|}
\hline \multicolumn{1}{|c|}{ Disease diagnosed at age in months } & No. & $\%$ age \\
\hline $0-6$ & 63 & $63 \%$ \\
\hline $7-12$ & 27 & $27 \%$ \\
\hline $13-36$ & 10 & $10 \%$ \\
\hline Total & 100 & $100 \%$ \\
\hline
\end{tabular}

Table 4 shows that family history of Thalassemia was present in $23 \%$ of the cases and history of consanguineous marriage was present in $4 \%$ of the cases.

Table-4: Distribution of the Patients According to the Family History of Thalassemia and Consaguineous Marriage of Parents.

\begin{tabular}{|l|l|l|l|l|}
\hline \multicolumn{2}{|c|}{ Family History } & Male & Female & Total \\
\hline \multirow{2}{*}{ Thalassemia } & Present & 15 & 8 & 23 \\
\cline { 2 - 6 } & Absent & 51 & 26 & 77 \\
\hline \multirow{2}{*}{ Consanguineous Marriage } & Present & 2 & 2 & 4 \\
\cline { 2 - 6 } & Absent & 64 & 32 & 96 \\
\hline \multirow{2}{*}{ Total } & No. of Patients & 66 & 34 & 100 \\
\hline
\end{tabular}

Table 5 shows that $41 \%$ of the parents knew that thalassemia is a blood disorder, $84 \%$ knew that it's a genetic disorder, $26 \%$ of the parents knew that 
There are 3 types of thalassemia Fifty seven percent of the parents knew the role of consanguinity. Seventy six percent of the parents knew about the prenatal diagnosis that could be performed to prevent the birth of thalassemic children.

Knowledge of the parents regarding importance of ferritin levels $(p=.002)$, role of chelation therapy
$(\mathrm{P}=.018)$ and bone marrow transplantation $(p=.033)$ was significantly related to the age of the patient.

Significant difference was found in the knowledge of parents in relation to geographical area. Knowledge regarding the disease and treatment option was more in parents from urban area.

\section{Table-5: Knowledge of the Patients about Thalassemia Disease and Its Management in Relation} with Age of the Patient.

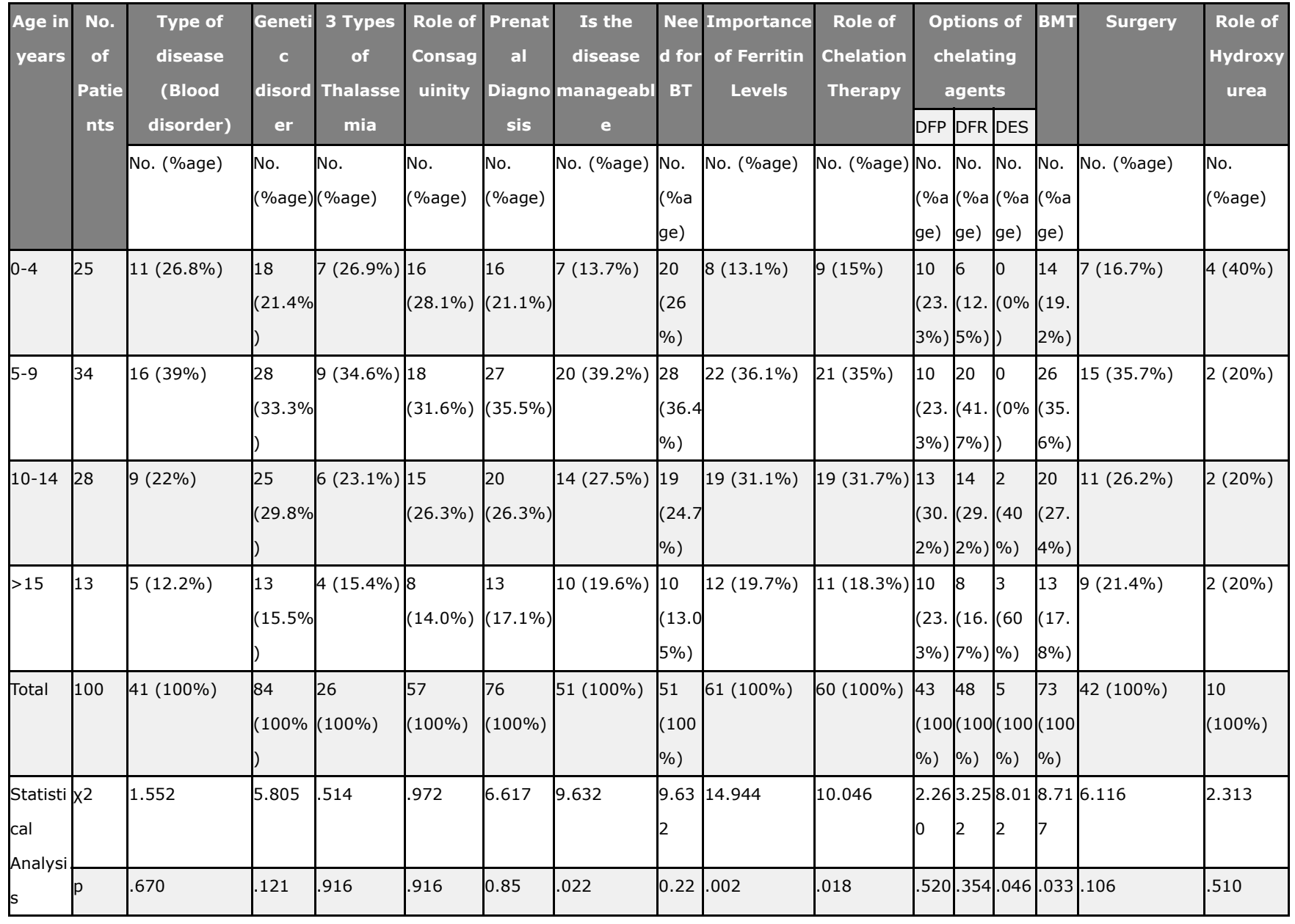


BT - Blood Transfusion, DFP- Deferiprone, DFRDeferasirox, DES- Desferrioxamine, BMT - bone Marrow Transfusion

Table 6 shows 38\% patients were from upper lower and $21 \%$ from lower middle and $2 \%$ of patients were from lower class. Only $1 \%$ was belonging to upper class.

The table also reveals that $76 \%$ of the parents knew about prenatal diagnosis, 79\% underwent prenatal diagnosis, $92 \%$ of parents were willing for abortion of thalassemia affected fetus, and $67 \%$ of the parents were adopting family planning methods.

Socioeconomic status-wise difference in attitude towards prenatal diagnosis $(p=.001)$ was statistically significant.

Table -6: Attitude of Parents towards Prevention of Disease in Relation to Socioeconomic Status (SES).

\begin{tabular}{|l|l|l|l|l|}
\hline \multicolumn{1}{|c|}{ SES } & \multicolumn{1}{|c|}{$\begin{array}{c}\text { No. of } \\
\text { Patients }\end{array}$} & $\begin{array}{c}\text { Undergone } \\
\text { Prenatal } \\
\text { Diagnosis }\end{array}$ & $\begin{array}{c}\text { Agree with } \\
\text { performing } \\
\text { abortion }\end{array}$ & $\begin{array}{l}\text { Adopting family } \\
\text { planning method }\end{array}$ \\
\cline { 3 - 5 } & No. (\% age) & No. (\%age) & No. (\%age) \\
\hline Upper & 1 & $1(1.3 \%)$ & $1(1.1 \%)$ & $1(1.5 \%)$ \\
\hline $\begin{array}{l}\text { Upper } \\
\text { Middle }\end{array}$ & 38 & $36(45.6 \%)$ & $37(40.2 \%)$ & $25(37.3 \%)$ \\
\hline $\begin{array}{l}\text { Lower } \\
\text { Middle }\end{array}$ & 21 & $19(24.1 \%)$ & $19(20.7 \%)$ & $14(20.9 \%)$ \\
\hline $\begin{array}{l}\text { Upper } \\
\text { Lower }\end{array}$ & 38 & $22(27.8 \%)$ & $33(35.9 \%)$ & $26(38.8 \%)$ \\
\hline Lower & 2 & $1(1.3 \%)$ & $2(2.2 \%)$ & $1(1.5 \%)$ \\
\hline Total & 100 & $79(100 \%)$ & $92(100 \%)$ & $67(100 \%)$ \\
\hline Statistical & $\times 2$ & 18.822 & 3.189 & .815 \\
\cline { 2 - 6 } Analysis & $\mathrm{p}$ & .001 & .527 & .936 \\
\hline
\end{tabular}

SES wise difference in attitude towards Prenatal diagnosis was found to be statistically significant.

Table 7 shows that $41 \%$ of the patients were from Khatri community and 59\% were from other communities. It depicts that knowledge regarding the treatment options available was found more in parents from Bania, Khatri and Kamboj communities.

Table 8 shows that $97 \%$ of children were coming for regular follow up, $73 \%$ of them were getting ferritin levels monitored, $74 \%$ were using chelating agents, $51 \%$ were using deferasirox, $19 \%$ deferiprone and only $1 \%$ was using desferrioxamine.

More positive attitude of parents towards prevention of thalassemia was found in parents who have
Answered 11-15 questions from Knowledge questionnaire. Table 9 shows that 36\% of the patients had effect of disease on their behaviour. Study was affected in $13 \%$ cases, $30 \%$ had temper tantrums, $17 \%$ developed abnormal physical features and growth of $26 \%$ children was affected.

Maximum number of patients whose growth was affected was from low socio-economic status, Effect on studies due to disease was more on patients from rural areas. Temper tantrums were present in more number of male patients. Prevention of Disease in Relation to Community.

\begin{tabular}{|c|c|c|c|c|}
\hline Commu & $\begin{array}{l}\text { No. of } \\
\text { Patients }\end{array}$ & $\begin{array}{c}\text { Undergone } \\
\text { Prenatal } \\
\text { Diagnosis }\end{array}$ & $\begin{array}{c}\text { Agree with } \\
\text { performing } \\
\text { abortion }\end{array}$ & $\begin{array}{l}\text { Adopting family } \\
\text { planning method }\end{array}$ \\
\hline & & No. (\%age) & No. (\%age) & No. (\%age) \\
\hline Baba & 1 & $0(0 \%)$ & $1(1.1 \%)$ & $1(1.5 \%)$ \\
\hline Bania & 7 & $1(3.1 \%)$ & $7(7.6 \%)$ & $7(10.4 \%)$ \\
\hline Bawalpur & 1 & $1(3.1 \%)$ & $1(1.1 \%)$ & $1(1.5 \%)$ \\
\hline Bazigar & 9 & $1(3.1 \%)$ & $8(8.7 \%)$ & $5(7.5 \%)$ \\
\hline Brahami & 1 & $0(0 \%)$ & $1(1.1 \%)$ & $0(0 \%)$ \\
\hline Chopra & 1 & $0(0 \%)$ & $1(1.1 \%)$ & $1(1.5 \%)$ \\
\hline $\begin{array}{l}\text { Goldsmit } \\
\text { h }\end{array}$ & 1 & $0(0 \%)$ & $1(1.1 \%)$ & $1(1.5 \%)$ \\
\hline Hindu & 2 & $0(0 \%)$ & $2(2.2 \%)$ & $1(1.5 \%)$ \\
\hline Jatt & 9 & $2(6.3 \%)$ & $6(6.5 \%)$ & $5(7.5 \%)$ \\
\hline Kamboj & 6 & $2(6.3 \%)$ & $6(6.5 \%)$ & $3(4.5 \%)$ \\
\hline Khatri & 41 & $19(59.4 \%)$ & $39(42.4 \%)$ & $28(41.3 \%)$ \\
\hline Kohli & 1 & $0(0 \%)$ & $1(1.1 \%)$ & $0(0 \%)$ \\
\hline Kumhar & 1 & $0(0 \%)$ & $1(1.1 \%)$ & $1(1.5 \%)$ \\
\hline Lohar & 1 & $0(0 \%)$ & $1(1.1 \%)$ & $1(1.5 \%)$ \\
\hline Lubana & 1 & $0(0 \%)$ & $1(1.1 \%)$ & $1(1.5 \%)$ \\
\hline Majbi & 1 & $0(0 \%)$ & $1(1.1 \%)$ & $1(1.5 \%)$ \\
\hline Mehra & 3 & $1(3.1 \%)$ & $3(3.3 \%)$ & $3(4.5 \%)$ \\
\hline Muslims & 1 & $1(3.1 \%)$ & $0(0 \%)$ & $1(1.5 \%)$ \\
\hline Naik & 1 & $0(0 \%)$ & $1(1.1 \%)$ & $0(0 \%)$ \\
\hline Nath & 1 & $0(0 \%)$ & $0(0 \%)$ & $1(1.5 \%)$ \\
\hline Rajput & 6 & $3(9.4 \%)$ & $6(6.5 \%)$ & $3(4.5 \%)$ \\
\hline \begin{tabular}{|l|} 
Ramdasi \\
\end{tabular} & 1 & $1(3.1 \%)$ & $1(1.1 \%)$ & $0(0 \%)$ \\
\hline Saadh & 1 & $0(0 \%)$ & $1(1.1 \%)$ & $1(1.5 \%)$ \\
\hline Saini & 1 & $0(0 \%)$ & $1(1.1 \%)$ & $1(1.5 \%)$ \\
\hline Sikh & 1 & $0(0 \%)$ & $1(1.1 \%)$ & $1(1.5 \%)$ \\
\hline Total & 100 & $32(100 \%)$ & 92 (100\%) & $67(100 \%)$ \\
\hline Statistica & $\mathrm{X} \square$ & 21.890 & 34.900 & 26.176 \\
\hline I Analysis & & .642 & .090 & .398 \\
\hline
\end{tabular}


Difference in attitude is not statistically significant in relation to their communities.

Table-8: Treatment Adherence of the Parents in Relation to their Disease Knowledge

\begin{tabular}{|c|c|c|c|c|c|c|c|c|}
\hline \multirow{3}{*}{$\begin{array}{l}\text { No. of questions answered } \\
\text { regarding knowledge }\end{array}$} & \multirow{3}{*}{$\begin{array}{c}\text { No. of } \\
\text { Patients }\end{array}$} & \multirow{2}{*}{$\begin{array}{l}\text { Regular } \\
\text { Follow up }\end{array}$} & \multirow{2}{*}{$\begin{array}{c}\text { Monitoring ferritin } \\
\text { levels }\end{array}$} & \multirow{2}{*}{$\begin{array}{l}\text { Using chelating } \\
\text { Agents }\end{array}$} & \multicolumn{3}{|c|}{ Regularly screened for } & \multirow{2}{*}{$\begin{array}{l}\text { Undergone } \\
\text { splenectomy }\end{array}$} \\
\hline & & & & & HIV & HBsAg & $\mathrm{HCV}$ & \\
\hline & & No. (\% age) & No. (\% age) & No. (\% age) & $\begin{array}{l}\text { No. }(\% \\
\text { age) }\end{array}$ & $\begin{array}{l}\text { No. }(\% \\
\text { age })\end{array}$ & $\begin{array}{l}\text { No. }(\% \\
\text { age })\end{array}$ & No. (\% age) \\
\hline $0-5$ & 31 & $29(29.9 \%)$ & $15(20.5 \%)$ & $13(17.6 \%)$ & $\begin{array}{l}24 \\
(27.9 \%)\end{array}$ & 6 & $6(12 \%)$ & $2(40 \%)$ \\
\hline $6-10$ & 48 & $47(48.5 \%)$ & $41(56.2 \%)$ & $42(56.7 \%)$ & $\begin{array}{l}44 \\
(51.2 \%)\end{array}$ & $\begin{array}{l}30 \\
(58.8 \%)\end{array}$ & $\begin{array}{l}30 \\
(60 \%)\end{array}$ & $1(20 \%)$ \\
\hline 11-15 & 21 & $21(21.6 \%)$ & $17(23.3 \%)$ & $19(25.7 \%)$ & $\begin{array}{l}18 \\
(20.9 \%)\end{array}$ & $\begin{array}{l}15 \\
(29.4 \%)\end{array}$ & $\begin{array}{l}14 \\
(28 \%)\end{array}$ & $2(40 \%)$ \\
\hline Total & 100 & $97(100 \%)$ & $73(100 \%)$ & $74(100 \%)$ & $\begin{array}{l}86 \\
(100 \%)\end{array}$ & $\begin{array}{l}51 \\
(100 \%)\end{array}$ & $\begin{array}{l}50 \\
(100 \%)\end{array}$ & $5(100 \%)$ \\
\hline \multirow[t]{2}{*}{ Statistical Analysis } & $x^{2}$ & 2.057 & 13.956 & 39.292 & 3.177 & 18.470 & 20.310 & 1.902 \\
\hline & p & .358 & .001 & .000 & .204 & .000 & .000 & .386 \\
\hline
\end{tabular}

Table-9: Psychosocial Problems in Relation to the Sex of the Patients.

\begin{tabular}{|l|l|l|l|l|l|l|}
\hline \multirow{2}{*}{ Sex } & No. of Patients & Effect on Behaviour & Effect on Studies & Temper Tantrums Present & Effect on Growth & Abnormal Physical Feature \\
\cline { 3 - 8 } & & No. (\%age) & No. (\%age) & No. (\%age) & No. (\%age) & No. (\%age) \\
\hline Male & 66 & $24(66.7 \%)$ & $10(76.9 \%)$ & $25(83.3 \%)$ & $19(73.15)$ & $14(82.4 \%)$ \\
\hline Female & 34 & $12(33.3 \%)$ & $3(9.7 \%)$ & $5(16.7 \%)$ & $7(26.9 \%)$ & $3(17.6 \%)$ \\
\hline Total & 100 & $36(100 \%)$ & $13(100 \%)$ & $30(100 \%)$ & $26(100 \%)$ & $17(100 \%)$ \\
\hline Statistical Analysis & $X 2$ & .011 & 1.050 & 6.201 & .784 & 2.441 \\
\cline { 2 - 7 } & $\mathrm{P}$ & .916 & .305 & .013 & .376 & .118 \\
\hline
\end{tabular}

Figure 1 shows that Maximum number of parents who were coming for regular follow up, monitoring ferritin levels of their children, whose children were using chelating agents and were screened for HIV, HBsAg and $\mathrm{HCV}$ i.e. $48.5 \%, 56.2 \%, 56.7 \%, 51.2 \%$, $58.8 \% \mathrm{~m} 60 \%$ were parents who gave $6-10$ correct answers. Also $100 \%$ i.e. $21 / 21,80.9 \%$ i.e. $17 / 21$, $90.5 \%$ i.e $19 / 21,85.7 \%$ i.e $18 / 21,71.4 \%$ i.e $15 / 21,66.7 \%$ i.e $14 / 21$ of parents who gave $11-15$ correct answers regarding disease knowledge were coming for regular follow up, monitoring ferritin levels of their children, using chelating agents and getting their children screened for HIV, HBsAg and $\mathrm{HCV}$ respectively. So relation of knowledge and treatment adherence was found statistically significant.

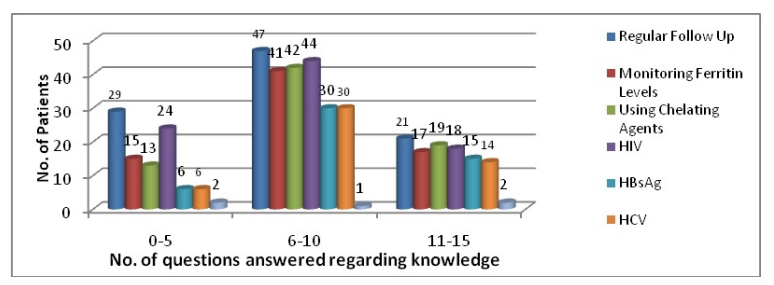

Figure-1: Treatment Adherence of the Parents in Relation to Their Disease Knowledge

\section{Discussion}

In this study, the parents of hundred thalassemia patients were interviewed at Thalassemia Day Care Centre of Pediatrics Department, Rajindra Hospital and Government Medical College, Patiala, Punjab. The parents were asked questions regarding knowledge about disease and various treatment options available, their attitude towards prevention of birth of thalassemia affected baby and practices followed by them as per pre-designed and pretested performa.

Various variables were compared using Chi Square test. Results so obtained were analyzed using SPSS version 15 software and level of significance was determined as its ' $p$ ' value with $p<0.05$ taken as statistically significant. In this study, $66 \%$ patients were males and $34 \%$ were females. This finding of male preponderance is in concordance with other studies done by Bandyopadhyay et al (2003); Shukr et al (2011); Yagnik (1997) and Sur et al (1998) [9] [10] [11] [12].

In our study $25 \%$ of the children were in age group $0-4$ years, $34 \%$ in $5-9$ years, $28 \%$ were in $10-14$ 
Years, $13 \%$ were $>15$ years. In other studies done by Shukr et al (2011) and Ishaq et al (2012) mean age of the patients was 9.5 years. There is no data available in literature to make age group wise comparison. (Table 1) [10] [13].

In our study, $43 \%$ of the patients were from rural area and $57 \%$ were from urban areas. There is no study available in literature to make geographical distribution wise comparison. (Table 2)

A study conducted by Upadhyay and Chatterjee (2009) shows similar results where $80 \%$ of the patients were diagnosed by the age of 3 year. This shows that maximum number of patients of thalassemia major became symptomatic in infancy and the rest in 1 st 3 years of life. (Table 3) [14].

In our study, family history of thalassemia was present in $23 \%$ of the cases and history of consanguineous marriages was present in $4 \%$ of the cases. Naseri et al (1997) in their study on status of thalassemia in Iran also reported that $66 \%$ of thalassemic children had consanguineous parents. The difference being due to the fact that consanguinity is high in Muslims. (Table 4) [15].

In our study $76 \%$ of the parents knew about prenatal diagnosis. This is in concordance with study done by Ishak et al (2012) which reported that 76.5\% parents knew about prenatal diagnosis[13].

In our study $51 \%$ of the parents knew that this disease is manageable. $77 \%$ of parents knew that blood transfusion is needed for growth of the child and to maintain hemoglobin levels and $61 \%$ of the parents knew the role of ferritin levels. Sixty of the parents knew role of chelation therapy, 43\% knew the option of deferiprone (Kelfer). (Table 5)

In this study majority of the parents belonged to middle class. This finding is not in concordance with a study done by Arif et al (2008) where majority of the parents were from low socioeconomic status[7].

In the present study $32 \%$ of the parents underwent prenatal diagnosis.Similar results were found in study done by Shukar et al (2011) [10].

In this study $92 \%$ of the parents were willing for abortion of thalassemia affected pregnancy. Similar results were shown in studies of Ahmad (2007) where majority of the parents and Karimi et al (2010) where $86.7 \%$ of the parents were in favor of termination of the affected foetus.

In our study majority of the parents were willing for termination of preqnancy with affected fetus
Because of poor outcome and prognosis and in those who were not willing for abortion the reason was emotional and religious in majority of them [16] [17].

Maximum number of parents who underwent prenatal diagnosis was from upper middle class. Socioeconomic status wise difference in attitude towards prenatal diagnosis was found statistically significant $(p=.001)$.There was no significant difference in the attitude of the parents towards prevention of disease in relation to geographical distribution and community as $\mathrm{p}$ values were $>.05$ for all the three variables. (Table 6)

This study showed that thalassemia is more prevalent in Khatri Community in Punjab. This is similar to the study conducted by Garewal et al (2003); where almost half the individuals belonged to the Khatri-Arora casts of Punjab (47.8\%). The remaining $52 \%$ were distributed amongst 13 other caste groups [5].

In the correlation of knowledge of the parents with geographical distribution is shown. A significant difference was found in the knowledge of parents from rural or urban area regarding the inheritance of disease $(p=.023)$, prenatal diagnosis $(p=.007)$, curability of the disease $(p=.000)$, importance of ferritin levels $(p=.010)$, role of chelation therapy $(p=.017)$. Knowledge regarding these aspects was more in parents from Bania, Khatri and Kamboj Community.

There is no study available in literature to make comparison while correlating knowledge of the parents with geographical distribution and community (Table7).

In this study knowledge of the parents regarding the inheritance and types of thalassemia, prenatal diagnosis, curability of the disease and need for blood transfusion was not different statistically in relation to the sex of the patient.

Likewise knowledge of the parents regarding importance of ferritin levels, role of chelation therapy, option of deferiprone and desferrioxamine, bone marrow transplantation (BMT), splenectomy and role of hydroxyurea was not different statistically in the relation of the sex of their children. (Table 8)

Similar results were shown in study conducted at Department of Psychiatry, National Institute of Mental Health and Neurosciences, Bangalore, by Shaligram et al (2007) 44\% children had 
Psychosocial problems. Canatan et al (2003) reported that education of $60 \%$ of thalassemic children of school age was affected. $82 \%$ of the parents had anxiety[18].

The recent emergence of oral iron chelation therapy (with deferiprone) has helped to lessen the burden of desferrioxamine infusion and thus is improving compliance Zahed et al (2002). (Table 9) [19].

Figure 1 shows the division of parents giving correct answers for knowledge questionnaire into three groups i.e. 1st giving 0-5 correct answers, 2nd giving 6-10 correct answers, 3rd included parents who gave 11-15 correct answers. Then the knowledge was correlated with treatment adherence.

Maximum percentage of parents who gave 11-15 correct answers, were monitoring ferritin levels of their children, giving chelating agents to their children, getting the screening for HIV, HBsAg, HCV done.

Relation between the treatment adherence and knowledge of the parents was found significant with $\mathrm{p}$ values $=.001, .000, .000, .000$ regarding monitoring of ferritin levels, use of chelating agents, screening for HBsAg and HCV.

This is in concordance with study done by Lee et al (2009) the score for the patient's disease knowledge about thalassemia major was positively correlated with follow-up visit adherence $(p<0.001)$ and with desferrioxamine infusion adherence $(p<0.001)$.

\section{Conclusion}

The following conclusions are drawn regarding the present study:-

- There should be a community based educational efforts to increase awareness of this problem especially to the people from low socioeconomic class and from rural area.

- Organizing regular awareness programmes and genetic counseling among high risk communities to inform them the salient facts about thalassemia, its hereditary nature, treatment and preventive possibilities is required. involvement of mass media is needed to achieve this goal.

- Premarital screening programmes aimed at identifying carrier individuals before marriages may be more effective and culturally acceptable among our communities as compared to
Prenatal diagnosis.

- It is evident from this study that thalassemia affects the psychosocial dimensions hence a more structural long term psychosocial support is needed to improve quality of life of patients.

\section{Contribution by Co-Authors}

Dr. Gurmeet and Dr. Kamaldeep Kaur conceived the idea of this study, guided the design, data collection and analysis, and wrote the initial draft of this paper. All the three contributed to the design, data collection and analysis. Dr. Kamaldeep Kaur with the help of Dr. Gurmeet Singh and Dr. Kanchan Bhardwaj contributed to data collection and analysis. Dr. Yash Mitra along with the author and co-authors contributed to the idea original article, and helped in corresponding the various activities to complete the article. All authors read and approved the final manuscript.

\section{What this Study adds to the Existing Knowledge}

It is evident from this study that thalassemic disease affects the psycho-social dimensions of the patient, family, community and leads to increase in the budget of the family as well as government to provide the treatment for the disease as well as psychosocial problems of the patient as a whole. Therefore, more structural and long-term psychosocial support in all of the above said aspects is needed to improve the quality of life of the patients suffering from thalassemic disease.

\section{Reference}

01. Mazzone L, Battaglia L, Andreozzi F, et al. Emotional impact in beta-thalassaemia major children following cognitive-behavioural family therapy and quality of life of caregiving mothers. Clin Pract Epidemiol Ment Health. 2009; Feb 23;5;5.

doi: [Article] [Crossref]

02. Miglani M, Lokeshwar MR. Transfusion therapy in thalassemia. Manual of Thalassemia. 2008;59. [Crossref]

03. Nair V, Nema SK, Chopra GS, et al. The First Allogeneic Bone Marrow Transplantation in the Armed Forces for Thalassemia. Med J Armed Forces India. $2005 \mathrm{Feb}$;61(2)190-1.

doi: 10.1016/S0377-1237 (05) 80025-5. Epub 2011 Jul 21 [Crossref] 
04. Lokeshwar MR, Shah N, Makrand D, Lokeshwar D. Thalassemia- Approach to the diagnosis. Manual of Thalassemia. 2008;3.

[Crossref]

05. Kukreti R, Dash D, E VK, et al. Spectrum of beta-thalassemia mutations and their association with allelic sequence polymorphisms at the beta-globin gene cluster in an Eastern Indian population. Am J Hematol. 2002;Aug;70(4)269-77.

[Crossref]

06. Madan N, Sharma S, Sood SK, Colah R, HM Bhatia. Frequency of $\beta$-thalassemia trait and other hemoglobin-pathies in northern and western India. Indian J Hum Genet. 2010; $16 ; 16-25$.

[Crossref]

07. Arif F, Fayyaz J, Hamid A. Awareness among parents of children with thalassemia major. J Pak Med Assoc. 2008;Nov;58(11)621-4.

[Crossref]

08. Lee YL, Lin DT, Tsai SF, Et al. Disease knowledge and treatment adherence among patients with thalassemia major and their mothers in Taiwan. J Clin Nurs. 2009;Feb;18(4)529-38.

doi: [Article] [Crossref]

09. Bandyopadhyay B, Nandi S, Mitra K, Mandal PK, Mukhopadhyay S, Biswas AB. A Comparative Study on Perceptions and Practices Among Parents Of Thalassemic Children Attending Two Different Institutions. Indian Journal of Community Medicine. $2003 ; 28 ; 3$. [Crossref]

10. Shukr et al. Attitude and knowledge of mothersAttitude and knowledge of mothers with thalassemia major children. Professional Med J. 2011;18(4)703-708.

[Crossref]

11. Yagnik $H$. Post counselling follow-up of thalassemia in high risk communities. Indian Pediatr. 1997;Dec;34(12)1115-8.

[Crossref]

12. Sen $P$, Mishra CP, Gupta VM, Dr PC Sen. Memorial Award- 1994 An epidemiological study of risk factors in preschool children of rural areas of Jaunpur District. Indian J Public Health. 1995;Apr-Jun;39(2)58-63.

[Crossref]
13. Ishaq $F$, Abid $H$, Kokab $F$, et al. Awareness among parents of $\beta$-thalassemia major patients, regarding prenatal diagnosis and premarital screening. J Coll Physicians Surg Pak. 2012 Apr;22(4)218-21. doi: [Article] [Crossref]

14. Upadhyay J and Chatterjee S. Assessment of the knowledge of thalassemia in the thalassemia patients and the treatment received by them. The Internet Journal of Hematology. $2009 ; 5 ; 2$. [Crossref]

15. Naseri et al. Status of Yang and Children with thalassemia major in Iran. Iran Thalassemia J. $1997 ; 12 ; 26-49$.

[Crossref]

16. Ahmad (2007). Attitude towards Genetic Diagnosis in Pakistan- A Survey of Medical and Lega Communities and Parents of Thalassemia Children. Public Health Genomics. 2007;10;3. [Crossref]

17. Karimi M, Johari S, Cohan N. Attitude toward prenatal diagnosis for beta-thalassemia major and medical abortion in Southern Iran. Hemoglobin. 2010;34(1)49-54. doi: [Article] [Crossref]

18. Shaligram et al. Psychological Problems and Quality of Life in Children with thalassemia. Indian J Pediatr. 2007;74(8)727-30.

[Crossref]

19. Zahed L, Mourad FH, Alameddine R, et al. Effect of oral iron chelation therapy with deferiprone (L1) on the psychosocial status of thalassaemia patients. Haematologia (Budap). 2002;31(4)333-9.

[Crossref] 